\title{
Sikap Siswa terhadap Pembelajaran Matematika melalui Model Pembelajaran Novick
}

\author{
Sri Rezeki ${ }^{1}$, Mutia $^{2}$ \\ ${ }^{1}$ Universitas Indraprasta PGRI, ${ }^{2}$ Institut Agama Islam Negeri Curup \\ ${ }^{1}$ srirezeki104@gmail.com, ${ }^{2}$ mutia@iaincurup.ac.id
}

\begin{tabular}{l}
\hline \hline Article Info \\
\hline Article history: \\
Received Oct $4^{\text {th }}, 2020$ \\
Revised Dec $31^{\text {th }}, 2020$ \\
Accepted Dec $31^{\text {th }}, 2020$ \\
\hline
\end{tabular}

Keywords:

Sikap Siswa;

Pembelajaran Novick; Matematika

Students' attitudes towards learning mathematics greatly affect student learning outcomes. If the attitude of students in the learning process gives a positive response, it will be easy for students to understand the material presented by the teacher, and vice versa if students give a negative response, then students will find it difficult to understand the material presented. This study aims to determine students' attitudes towards learning activities by applying the Novick learning model. This type of research is a type of qualitative research. The method used in this research is distributing questionnaires to students. The results showed that the students' attitudes towards Novick's learning model were quite positive. Students generally expressed their joy and enthusiasm in participating in the Novick learning model.

\section{Kata Kunci:}

Students Attitude;

Novick Learning;

Mathematics
Sikap siswa terhadap pembelajaran matematika sangat berpengaruh terhadap hasil belajar siswa. Jika sikap siswa dalam proses belajar memberikan respon yang positif, maka akan mudah bagi siswa dalam memahami materi yang disampaikan oleh guru, dan sebaliknya jika siswa memberikan respon yang negatif, maka siswa akan sulit dalam memahami materi yang di sampaikan. Penelitian ini bertujuan untuk untuk mengetahui sikap siswa terhadap kegiatan pembelajaran dengan menerapkan model pembelajaran Novick. Jenis penelitian ini merupakan jenis penelitian kualitatif. Metode yang digunakan dalam penelitian ini adalah penyebaran angket kepada siswa. Hasil penelitian menunjukkan bahwa sikap siswa terhadap model pembelajaran Novick adalah cukup positif. Siswa pada umumnya menyatakan senang dan semangat mengikuti pembelajaran dengan model pembelajaran Novick. 


\section{PENDAHULUAN}

Pendidikan merupakan suatu hal yang penting dalam kehidupan manusia, karena pendidikan dapat mengembangkan potensi-potensi yang dimiliki oleh seseorang, serta dapat membentuk akhlak, sikap dan kepribadian yang baik. Pendidikan di sekolah tidak terlepas dari interaksi antara guru dan siswa dalam proses pembelajaran di kelas. Pembelajaran yang interaktif dan menyenangkan di kelas merupakan hal yang penting dalam proses pembelajaran, khususnya pada mata pelajaran matematika karena matematika sampai saat ini masih menjadi mata pelajaran yang sulit bagi siswa.

Pembelajaran matematika yang interaktif dapat memberikan pengaruh positif terhadap sikap siswa. Namun sampai saat ini, pada proses pembelajaran di kelas masih ada pembelajaran matematika yang bersifat satu arah atau berpusat pada guru, dimana guru lebih aktif menjelaskan materi dan siswa hanya menerima saja penjelasan dari guru. Sehingga pembelajaran yang demikian membuat siswa cepat merasa bosan dan cenderung tidak menyukai pelajaran matematika, akibatnya dapat memberikan pengaruh atau sikap yang negatif oleh siswa terhadap pembelajaran matematika. Menurut penelitian yang dilakukan oleh (Atiaturrahmaniah \& Rahayu, 2018) sebagian besar siswa mengikuti proses pembelajaran dengan baik meskipun masih ada beberapa siswa pada saat mengikuti pembelajaran matematika di kelas terlihat tidak memperhatikan penjelasan guru. Salah satu penyebabnya adalah guru kurang memperhatikan sikap siswa terhadap matematika itu sendiri. Akibatnya, siswa kurang memahami materi yang dijelaskan oleh guru dan siswa juga kurang termotivasi dalam mengikuti pembelajaran matematika. Padahal sikap dan kemampuan matematis siswa ini merupakan salah satu faktor yang mempengaruhi hasil belajar siswa di kelas.

(Lestariningsih \& Sholichah, 2017) menyatakan bahwa pembentukan sikap pada siswa pada proses pembelajaran membutuhkan waktu, sikap tersebut dapat terbentuk dari interaksi antara siswa dengan pelajaran matematika. Pembelajaran matematika yang interaktif dapat dilakukan dengan membentuk kelompok-kelompok kecil di kelas. Siswa 
dapat melakukan diskusi bersama teman kelompoknya, dengan kelompok lainnya, serta dengan guru, dengan demikian siswa menjadi lebih aktif dalam proses pembelajaran, sehingga pembelajaran terasa lebih menyenangkan. Dengan demikian sikap siswa terhadap pembelajaran matematika juga berdampak positif.

Menurut Stiles et al. (Suhandri, 2011) sikap siswa terhadap matematika sangat penting karena dengan kepercayaan diri siswa terhadap matematika maka mereka akan menghargai dan menikmati matematika yang berkaitan erat dengan kesiapan mereka untuk belajar matematika dan prestasi siswa berikutnya dalam matematika. Menurut Callahan (Suhandri, 2011) siswa mengembangkan sikap positif terhadap matematika ketika mereka melihat matematika sebagai sesuatu yang berguna dan menarik. Demikian pula sebaliknya, siswa akan mengembangkan sikap negatif terhadap matematika ketika mereka tidak melakukannya dengan baik atau melihat matematika sebagai sesuatu yang tidak menarik. Jadi, sikap merupakan suatu respon, pola perilaku serta kesiapan antisipatif seseorang terhadap suatu kondisi atau objek di lingkungan sekitarnya, sehingga timbulnya perasaan mendukung atau tidak mendukung dari lingkungannya tersebut. Yudhi (Herlina, 2012) menyatakan bahwa agar siswa dapat menerima pelajaran matematika atau memberikan respon positif setelah mengikuti pelajaran matematika, guru perlu menanamkan sikap positif siswa terhadap matematika. Dengan kata lain, dalam proses pembelajaran matematika perlu diperhatikan sikap positif siswa terhadap matematika. Artinya, setelah siswa belajar matematika, sikap siswa lebih positif terhadap matematika (mempunyai respon positif atau lebih menyukai matematika). Sikap positif siswa terhadap pelajaran menjadi hal yang sangat penting untuk meningkatkan kepercayaan diri siswa untuk meningkatkan prestasi dalam belajar.

Sikap siswa terhadap pembelajaran matematika sangat berpengaruh terhadap hasil belajar siswa. Jika sikap siswa dalam proses belajar memberikan respon yang positif, maka akan mudah bagi siswa dalam memahami materi yang disampaikan oleh guru, dan sebaliknya jika siswa memberikan respon yang negatif, maka siswa akan sulit dalam memahami materi yang di sampaikan. Oleh karena itu guru mempunyai 
peran penting dalam menumbuhkan sikap positif siswa terhadap pembelajaran matematika.

Salah satu model pembelajaran yang dapat diterapkan agar pembelajaran matematika yang interaktif yaitu model pembelajaran Novick. Model pembelajaran Novick ini merujuk dari pandangan konstruktivis dalam membentuk pengetahuan siswa, di mana siswa lebih ditekankan dalam mengkonstruksi ide-idenya yang sudah ada sebelumnya dalam proses pembelajaran. Driver dkk. (Natsir, 1997) menurut konstruktivis ketika masuk kelas untuk menerima pelajaran, siswa tidak dengan kepala kosong yang siap diisi dengan berbagai macam pengetahuan oleh guru. Lebih lanjut dijelaskan, mereka telah membawa pengetahuan awal yang diistilahkan oleh para konstruktivist dengan children's idea, cognitive structure, alternative framework, children's models, alternative conception dan sebagainya. Dengan menerapkan model pembelajaran ini, diharapkan siswa lebih aktif dalam belajar dengan mengungkapkan pendapat atau idenya yang bisa direpresentasikan melalui gambar atau kata-kata. Jadi dengan menerapakan model pembelajaran Novick ini, diharapkan dapat menumbuhkan sikap positif siswa terhadap pembelajaran matematika.

\section{METODE PENELITIAN}

Metode penelitian yang digunakan dalam penelitian ini yaitu deskriptif kualitatif. Penelitian ini dilakukan pada salah satu SMA swasta di Kota Bandung. Peneliti menyebarkan angket skala sikap siswa yang diberikan pada kelas eksperimen, tujuannya untuk melihat sikap siswa terhadap pembelajaran matematika melalui model pembelajaran Novick. Angket skala sikap disusun berdasarkan skala Likert, pernyataanpernyataan yang diajukan, baik pernyataan positif maupun negatif, dinilai oleh subjek dengan sangat setuju, setuju, tidak punya pendapat, tidak setuju, sangat tidak setuju (Sudjana, 2017). Namun pada penelitian ini, peneliti tidak menggunakan pernyataan yang bernilai tidak punya pendapat, hal ini bertujuan untuk menghindari jawaban netral dari siswa yang nantinya tidak menunjukkan kejelasan sikap. Instrumen skala sikap pada penelitian ini terdiri dari 21 butir pertanyaan dan diberikan kepada 
siswa kelompok eksperimen setelah semua kegiatan pembelajaran berakhir. Skor yang diperoleh dari setiap pernyataan ditransformasi ke Method Succesive Interval (MSI). Untuk mengetahui sikap siswa, siswa mempunyai sikap positif atau negatif maka rataan skor setiap siswa dibandingkan dengan skor netral yaitu 2,5. Bila rataan skor seorang siswa lebih kecil dari skor netral, artinya siswa mempunyai sikap negatif. Sedangkan bila rataan skor seorang siswa lebih besar dari skor netral, artinya siswa mempunyai sikap positif.

\section{HASIL PENELITIAN DAN PEMBAHASAN}

Pengisian angket skala sikap siswa bertujuan untuk mengetahui sikap siswa terhadap kegiatan pembelajaran dengan model pembelajaran Novick. Angket skala sikap ini hanya diberikan kepada siswa kelas eksperimen yang terdiri dari 21 pernyataan. Sikap siswa yang akan dianalisis yaitu sikap siswa terhadap pelajaran matematika, sikap siswa terhadap pembelajaran dengan model pembelajaran Novick.

Perhitungan skor sikap siswa dimulai dengan menghitung rataan masing-masing pernyataan, baik pernyataan positif dan negatif. Kemudian dihitung rataan skor sikap untuk tiap-tiap aspek sikap siswa dan membandingkannya dengan skor netral yaitu 2,5. Bila rataan skor sikap lebih besar dari skor netral, maka siswa mempunyai sikap positif, namun jika rataan skor sikap lebih kecil dari skor netral, maka siswa mempunyai sikap yang negatif.

Berikut ini akan disajikan distribusi skor sikap siswa terhadap pembelajaran dengan model pembelajaran Novick.

Tabel 1 Skor Rerata Sikap Siswa terhadap Pembelajaran

Matematika

\begin{tabular}{llcr}
\hline \multicolumn{1}{c}{ Aspek } & \multicolumn{1}{c}{ Indikator } & $\begin{array}{c}\text { Rerata } \\
\text { Indikator }\end{array}$ & $\begin{array}{l}\text { Sikap } \\
\text { Siswa }\end{array}$ \\
\hline $\begin{array}{l}\text { Sikap siswa terhadap } \\
\text { pembelajaran } \\
\text { matematika }\end{array}$ & $\begin{array}{l}\text { Menunjukkan } \\
\text { kesenangan } \\
\text { terhadap pelajaran } \\
\text { matematika }\end{array}$ & 2,733 & Positif \\
& & & \\
\hline
\end{tabular}




$\begin{array}{llll}\begin{array}{l}\text { Menunjukkan } \\ \text { kesungguhan }\end{array} & \text { dalam } & & \\ \begin{array}{l}\text { mengikuti } \\ \text { pembelajaran }\end{array} & & & \\ \text { matematika } & & & \\ & & & \\ \end{array}$

Berdasarkan Tabel 1 diperoleh gambaran bahwa siswa memiliki sikap positif terhadap pelajaran matematika. Hal itu terlihat pada rata-rata indikator sikap positif siswa terhadap pelajaran matematika yaitu 2,733. Rata-rata indikator yang menunjukkan kesungguhan dalam mengikuti proses pembelajaran matematika yaitu 2,706. Jika dibandingkan dengan skor netral, maka masing-masing indikator memiliki rata-rata yang lebih besar daripada skor netral yaitu 2,5. Jadi, dapat disimpulkan sebagian siswa memiliki sikap yang positif terhadap pelajaran matematika.

Berdasarkan penelitian yang dilakukan oleh (Lestariningsih \& Sholichah, 2017) sikap positif yang terdapat pada siswa terhadap pelajaran matematika membuat siswa cenderung lebih tertarik dan berusaha mempelajari matematika. Hal ini juga sependapat dengan (Kemendikbud RI, 2015) jika siswa bersikap positif terhadap suatu obyek sikap, maka akan menimbulkan perilaku yang positif, ditandai oleh kecenderungan tindakan untuk mendekati, menyenangi dan mengharapkan obyek sikap yang dihadapinya. Sebaliknya, apabila siswa bersikap negatif maka ditandai adanya kecenderungan menjauh, menghindar, membenci dan tidak menyukai obyek tersebut. Artinya, jika siswa tersebut menunjukkan sikap cenderung lebih menyenangi dan semangat dalam mengikuti pelajaran matematika, maka siswa tersebut menunjukkan sikap yang positif terhadap pembelajaran matematika.

Adapun Tabel 2 di bawah ini menunjukkan skor rerata siswa terhadap model pembelajaran Novick. Rata-rata indikator sikap siswa yang menunjukkan kesukaan terhadap model pembelajaran Novick yaitu 2,797 dan rata-rata indikator peran guru dalam pembelajaran 2,594. Jika dibandingkan dengan skor netral, maka rata-rata kedua indikator lebih besar dari skor netral yaitu 2,5, artinya siswa menunjukkan sikap positif terhadap kedua indikator tersebut. Jadi, dapat disimpulkan bahwa 
sebagian siswa memliki sikap yang positif terhadap pembelajaran dengan model pembelajaran Novick.

Tabel 2 Skor Rerata Sikap Siswa terhadap Model Pembelajaran Novick

\begin{tabular}{cccc}
\hline Aspek & Indikator & $\begin{array}{c}\text { Rerata } \\
\text { Indikator }\end{array}$ & $\begin{array}{c}\text { Sikap } \\
\text { Siswa }\end{array}$ \\
\hline $\begin{array}{c}\text { Sikap siswa } \\
\text { terhadap } \\
\text { pembelajaran } \\
\text { dengan } \\
\text { model } \\
\text { pembelajaran } \\
\text { Novick }\end{array}$ & $\begin{array}{c}\text { Menunjukkan } \\
\text { kesukaan terhadap } \\
\text { pembelajaran } \\
\text { dengan model } \\
\text { pembelajaran } \\
\text { Novick }\end{array}$ & 2,797 & Positif \\
\cline { 2 - 4 } & $\begin{array}{c}\text { Peran guru dalam } \\
\text { pembelajaran }\end{array}$ & \\
& & 2,594 & Positif \\
& & & \\
\hline
\end{tabular}

Berdasarkan tanggapan siswa melalui angket skala sikap yang diperoleh bahwa secara umum tanggapan siswa terhadap pembelajaran matematika dengan menerapkan model pembelajaran Novick dikatakan cukup baik. Hal ini tidak terlepas dari rancangan pembelajaran dan cara guru dalam menyajikan pembelajaran. Hasil tanggapan siswa dilihat dari distribusi skala sikap siswa yang menunjukkan bahwa siswa memiliki sikap yang cukup positif terhadap pelajaran matematika dan model pembelajaran Novick. Hal ini terlihat dari aktivitas siswa yang semakin meningkat dari setiap pertemuan. Para siswa begitu antusias dalam mengikuti pembelajaran, baik dalam diskusi kelompok maupun diskusi kelas.

Sikap siswa terhadap model pembelajaran ini juga dapat dilihat dari kesenangan dan kesungguhan siswa dalam mengikuti pembelajaran. Sikap positif dapat dilihat dari kesungguhan siswa dalam merepresentasikan ide-idenya dalam mengungkap konsepsi awal siswa, serta adanya kesungguhan siswa di saat guru menciptakan konflik konseptual, dimana siswa tertantang untuk mencari jawaban yang benar 
dari persepsi awalnya yang kontradiksi dengan pernyataan yang diberikan oleh guru.

\section{SIMPULAN}

Sikap siswa terhadap model pembelajaran Novick adalah cukup positif. Siswa pada umumnya menyatakan senang dan semangat mengikuti pembelajaran dengan model pembelajaran Novick. Hal ini terlihat dari aktivitas siswa yang semakin meningkat dari setiap pertemuan. Para siswa begitu antusias dalam mengikuti pembelajaran, baik dalam diskusi kelompok maupun diskusi kelas.

\section{DAFTAR PUSTAKA}

Atiaturrahmaniah, A., \& Rahayu, S. (2018). Hubungan Sikap Matematika Dengan Hasil Belajar Siswa Kelas V Sdn 06 Montong Baan. Jurnal DIDIKA: Wahana Ilmiah Pendidikan Dasar, 4(2), 58. https://doi.org/10.29408/didika.v4i2.1202

Herlina, S. (2012). Efektivitas Strategi React dalam Upaya Peningkatan Kemampuan Komunikasi dan Pemecahan Masalah Matematis Siswa Sekolah Menengah Pertama. Universitas Pendidikan Indonesia.

Kemendikbud RI. (2015). Penilaian Sikap Spiritual dan Sosial. Jakarta: Pusat Penilaian Pendidikan Balitbang Kementerian Pendidikan dan Kebudayaan Republik Indonesia.

Lestariningsih, L., \& Sholichah, B. (2017). Pengaruh Sikap Siswa Pada Matematika terhadap Hasil Belajar Materi Persamaan Kuadrat. Jurnal Pendidikan Matematika RAFA, 3(2), 207-213. https://doi.org/10.19109/jpmrafa.v3i2.1742

Natsir, M. (1997). Strategi Penggunaan Model Pembelajaran Novick untuk Meningkatkan Keaktifan dan Pemahaman Siswa tentang Listrik dalam Pembelajaran IPA di SD. Universitas Pendidikan Indonesia.

Sudjana, N. (2017). Penilaian Hasil Proses Belajar Mengajar (21st ed.). Bandung: PT Remaja Rosdakarya. 
Suhandri. (2011). Meningkatkan Pemahaman dan Penalaran Matematis Siswa SMP pada Pembelajaran Geometri dengan Menggunakan Strategi REACT (Universitas Pendidikan Indonesia). Retrieved from http://repository.upi.edu/id/eprint/10243 
178 | Rezeki dan Mutia: Sikap Siswa terhadap Pembelajaran Matematika Melalui ... 